
\title{
is Research Square \\ Health-related Quality of Life Profile of Indonesian Children and Its Determinants: a Community-based Study
}

Mei Neni Sitaresmi ( $\square$ msitaresmi@ugm.ac.id)

Universitas Gadjah Mada/ DR Sardjito Hospital

Braghmandita Widya Indraswari

Universitas Gadjah Mada/ DR Sardjito Hospital

Nisrina Maulida Rozanti

Universitas Gadjah Mada (UGM)

Zena Sabilatuttaqiyya

Universitas Gadjah Mada (UGM)

Abdul Wahab

Universitas Gadjah Mada (UGM)

\section{Research Article}

Keywords: health-related quality of life, children, acute illness, sociodemographic, low- and middle-income countries

Posted Date: August 24th, 2021

DOl: https://doi.org/10.21203/rs.3.rs-824073/v1

License: (1) This work is licensed under a Creative Commons Attribution 4.0 International License. Read Full License

Version of Record: A version of this preprint was published at BMC Pediatrics on February 22nd, 2022. See the published version at https://doi.org/10.1186/s12887-022-03161-0. 


\section{Abstract}

Background: Assessing health-related quality of life (HRQOL) and its determinants in children may provide a comprehensive view of child health. The study aimed to assess the HRQOL in Indonesian children and its determinants.

Methods: We conducted a community-based cross-sectional study in the Sleman District of Yogyakarta Special Province, Indonesia, from August to November 2019. We recruited children aged 2 to 18 years old using the Sleman Health and Demography Surveillance System sample frame. We used the validated Indonesian version of Pediatric Quality of life Inventory ${ }^{T M}$ (Peds QL ${ }^{T M}$ ) 4.0 Generic core scale, proxyreports, and self-reports, to assess the HRQOL.

Results: We recruited 633 proxies and 531 children aged 2-18 years. The mean total score of self-report and proxy-report were $89.9 \pm 8.5$ and $93.3 \pm 6.4$. There was a fair to moderate correlation between selfreports and proxy reports, with interclass correlation ranging from 0.34 to 0.47 , all $p<0.001$. Half of the children (49.4\% from proxy-report and $50.1 \%$ from self-report) reported having acute illness during the last month. Based on proxy-reports, multivariate regression analysis demonstrated lower HRQOL for children with acute health problems, younger age, history of low birth weight, abnormal delivery, lower fathers' educational level, and government-paid insurance for low-income families.

Conclusion: In addition to sociodemographic determinants of a child's HRQOL, children's health condition influences $\mathrm{HRQOL}$ in the general pediatric population. In low- and middle-income countries where acute infections and low birth weight are still prevalent, its prevention and appropriate interventions should improve child health.

\section{Background}

Assessing child health conventionally has focused on morbidity and mortality. Moreover, mortality is not a sufficiently sensitive outcome in children older than two years old, and it may not provide a comprehensive view of child health. On the other hand, health-related quality of life (HRQOL) can give a broader aspect of health according to the WHO constitution, including aspects of perceived health, psychosocial, mental health, and well-being [1]. Therefore, HRQOL can measure child health in the general population more comprehensively and provide better identification of unrecognized conditions, social and emotional problems, and poor functioning [2]. Measuring HRQOL in the pediatric population can help determine the burden of disease and assess the impact of prevention and intervention. Measuring HRQOL may also assist in the evaluation of the health care needs of a community. Self-assessed health status is also a more powerful predictor of mortality and morbidity than many objective measures of health [3].

Previous studies showed some determinants of HRQOL in children and adolescents, such as sociodemographic factors, gender, age, and health status. Lower parental income and lower parental educational level were associated with lower HRQOL [4]. The number of health problems and health care visits are negatively correlated with $\operatorname{HRQOL}[5,6]$. Perinatal factors such as birth weight and gestation age 
were related to HRQOL in adolescence [7]. Many studies, most of them from high-income countries, compared HRQOL between healthy children and children with chronic conditions [5, 8, 9]. In Indonesia, as a low- and middle-income country, the prevalence of acute illness and low birth weight are still high [10]. Therefore, it is crucial to assess the influence of acute disease and low birth weight on HRQOL. The study aimed to evaluate the HRQOL in children aged 2-18 years in the general population and its determinants.

\section{Methods}

Study design

We conducted a community-based cross-sectional study in the Sleman District of Yogyakarta Special Province, Indonesia. Sleman District, a semi-urban city, consists of 17 sub-districts and 86 villages and is $574.82 \mathrm{~km}^{2}$ wide, with the population of $1,167,481$ and $29.5 \%$ are under 20 years old [11]. We included parents of children aged 2-18 years old and children 5-18 years old. We excluded children with chronic health problems, major congenital conditions, and children who were hospitalized during data collection. Considering the total population of children and level of confidence $95 \%$, the sample size was 600 subjects. A cluster sampling approach was used to collect the sample from children in The Health and Demographic Surveillance System (HDSS) sample frame in Sleman, Yogyakarta. The Sleman HDSS is a longitudinal household-based survey, and the survey was conducted annually, starting in 2015 [11]. Ethical approval was obtained from the Medical and Health Research Ethics Committee of the Faculty of Medicine, Public Health and Nursing.

Written informed consent was obtained from all parents/guardians of the children 2-18 years, and assent of 11-18 years old children. Participation was voluntary, and confidential was ensured.

Instruments and measurements

Data were collected by trained interviewers at a home visit through a Computer-Assisted Personal Interview on a tablet device. The data were transferred to the server through the Internet. The quality control consisted of spot-checks of $5 \%$ of interviews to control adherence to the protocol, re-checks to ensure the validity of the interview, and computer-based data cleaning. Sociodemographic data includes parental data on educational level ( $<9$ years is considered as low education level), working status, living area (urban and rural-based on the listing from the Indonesia statistic) and health insurance ownership (government-paid for poor families, self-funding for more prosperous families). Children's data included age, gender, birth weight (birth weight $<2,500$ gram is considered as low birth weight or LBW), mode of delivery, and health condition (if the child suffered from fever, diarrhea, vomiting, cough, and other symptoms during the last month).

HRQOL was assessed using The Indonesian Validated Version of Pediatric Quality of life Inventory ${ }^{\mathrm{TM}}$ $\left(P e d s Q L^{\top M}\right.$ ) 4.0 Generic Core Scale. A cultural-linguistic validation test has been conducted by Sitaresmi et al. [12]. The PedsQL ${ }^{T M}$ is a multidimensional instrument developed by Varni et al. [13]. It consists of 23 items categorized into four subscales: physical functioning (8 items), emotional functioning (5 items), 
social functioning ( 5 items), and school functioning ( 5 items). For interpretation, three scores can be obtained: physical health (score of the physical functioning subscale), psychosocial health (combined scores of the emotional functioning, social functioning, and school functioning subscales), and the total score (combined score of physical health and psychosocial health). The PedsQL is available for children aged: $5-7,8-12$, and $13-18$ years old, as well as for the guardian of children aged: $2-4,5-7,8-12$, and 13-18 years old. The scale has five Likert response options: never, almost never, sometimes, often, and almost always. To simplify the interpretation, all Likert scales were converted to $0-100$. The higher scores indicate a higher HRQOL. For the versions adapted to children between the ages of 5 and 7 years, there are only three response options: never, some- times, and almost always (corresponding to 100,50, 0 ). For this age, a Face Scale was used, comprising 3 pictures of facial expressions varying from a smiling face to a very sad face to indicate no problem/difficulty to a lot of problems/difficulty.

Statistical analysis

We used EpiData for data management, and data analysis was performed with SPSS version 25 for Windows. Baseline characteristics were first described using mean, median, or proportion as appropriate. Mean presented by calculation of total score of HRQOL for each subject. We compared scores between different demographic characteristics using the Independent-Sample T-Test. To identify variables that most closely predict the HRQOL score, we conducted backward multiple regression analysis for each PedsQL ${ }^{\mathrm{Tm}}$ subscale as the dependent variable and sociodemographic characteristic and health status as an independent variable. Analyses were performed with two-sided tests, and a p-value $<0.05$ was considered significant. Agreement between child self-report and parent proxy-report on the PedsQL ${ }^{\mathrm{Tm}} 4.0$ was assessed using Inter-Class Correlation (ICC) values.

\section{Results}

\section{Participant characteristics}

A total of 633 guardians, most of them were mothers (77\%), and 538 children were recruited. Table 1 shows that there were slightly more boys $(51.8 \%)$ than girls, with the mean age was $10.40 \pm 4.7$ years. Half of the children both from self-report and proxy-report reported suffering from acute illness, with the most comments symptoms were cough/coryza (37.8\%), fever (12.5\%), and diarrhea (2.5\%). A higher proportion of 2-12 years old children (56\%) suffered from an acute illness compared to the adolescence group (38\%). Table 2 shows the mean score of self-reports and proxy-reports. Both from self-reports and proxy-reports, school functioning was the lowest score. There was a fair to moderate agreement between self-reports and proxy reports, with ICC range from 0.38 to 0.49 . (Table 2 ).

Bivariate Analysis

Table 3 shows that the number of children, child position in the family, father educational level, working parents' status, living area, health insurance ownership, and child health status are significantly related to HRQOL based on the self-report. Table 4 shows that child age, birth weight, mode of delivery, father 
education level, health insurance ownership was significantly related to HRQOL based on the proxy report. A higher total mean score was found in adolescents with normal birth weight, normal delivery, higher level of father's education, and self-funding Insurance based on the proxy report. Both children and their guardians did not report any significant gender differences in HRQOL.

Multivariate analysis

In linear regression models, variables included in the final model for the total mean score of child-report were child health status, number of children, living area, and father education level. Children who suffered from acute illness during the last month, children with lower fathers' education level, and who live in an urban area perceived lower HRQOL than their counterparts. For proxy-reports, the final regression model for the total mean score included children's age, children's health status, birth weight, mode of delivery, fathers' education level, and insurance ownership. The coefficients and corresponding confidence intervals are presented in Table 5.

\section{Discussion}

Measuring HRQOL and its determinants in the pediatric population can provide insight into developing more targeted public health policies planned by multiple stakeholders [14]. To our knowledge, this study was the first study assessing HRQOL and its determinants in the general pediatric population in Indonesia. Surprisingly, the total score of $\mathrm{HRQOL}$ in our general pediatric population is higher than those in the references study by Varni et al., $89+9$ vs $84+12$ (self-reports) and $92+6$ vs $82+15$ (proxy-reports) [15]. However, the mean total score of our study was similar to the scores from healthy children in India $(87 \pm 11)$ for self-reports and $90 \pm 9$ for proxy reports) [16]. This may be explained by the fact that our population positively perceived and were satisfied with their life. According to WHO, quality of life is a personal perception of their position in life in the context of their culture and value system and related to their goals, expectations, values, and concerns [17].

In both self-reports and proxy reports, the school functioning was the lowest score among the other domains. It may be explained by almost half of our respondents, especially in the age of 2-12 years, had an acute illness. It may result in school absences and lower the school score. This finding is similar to the study assessing HRQOL of children with acute febrile illness [14] and in bronchitis children [18] which used the PedsQL ${ }^{\text {Tw}}$ and found the school functioning was the lowest score.

Sociodemographic determinant of Child HRQOL

We found some sociodemographic characteristics related to children's HRQOL. Children who were living in the rural area reported better HRQOL than their urban counterparts. This is remarkable, considering the rural area is associated with a low-resource setting. The finding may probably be due to different perceptions or expectations about HRQOL and life amenities between rural and urban children [16]. As reported by a previous study [19], we found that children with higher father's education level had higher HRQOL, both from the self-reports and proxy reports. Higher levels of parent's education might increase 
parent's awareness and knowledge about their children's health and supported to get better occupations and income, which led to better HRQOL and life expectancy [19]. On the contrary, we did not find any influence of maternal educational level on children's HRQOL. It may be explained by the fact that in most of Indonesia's families, fathers still hold the leading role. Indonesia is using a patriarchal system which is still common in society and generally accepted by the community. This system raises the principle and value that all the family's decisions, including children's education and health-seeking behavior, are managed by the fathers [20].

A previous study found the health insurance ownership influenced a child's HRQOL [21]. We found that children from self-funding insurance families had higher HRQOL scores than children from families with government-paid insurance or no insurance, both from proxy-reports as well as self-reports. In our population, health insurance ownership may indirectly reflect family socioeconomic status. Since 2014, the Indonesian government introduced National Health Insurance. This obligatory national health insurance system combines government-paid health insurance for poor families and contributory-based (self-funding) health insurance for the more prosperous families [22]. In addition, people with health insurance receive more appropriate and recommended use of health services and have better health outcomes. In contrast, people with no insurance are less likely to receive preventive and screening services, regular and continuing source of care [23].

Interestingly, our adolescence group had higher HRQOL than younger children. This finding contradicts previous studies that found declining HRQOL with increasing age [24]. It may be related to the higher prevalence of acute disease in younger Indonesia's children. We found a higher proportion of 2-12 years old children (56\%) suffered from an acute illness than the adolescent group (38\%).

Child health determinants on Child HRQOL

Most studies assessing the influences of chronic health problems on a child's HRQOL $[5,14,19]$, but few studies assessed the influence of acute illness. A study on determinants of HRQOL in Dutch school-age children's in the general population found that children who had acute health complaints showed lower scores of HRQOL [5]. Our study found that the best predictor of children's HRQOL was the presence of acute illness during the past month. In multivariate regression analysis, we consistently found that having an acute disease, such as upper respiratory symptoms and diarrhea, during the past month lowers the child's HRQOL from the self-reports and proxy reports across all domains. More than one-third of our children have cough or/and coryza, with or without fever, during the past month. We excluded children who were hospitalized during the past last month. Our sample represented that upper respiratory tract symptoms are a prevalent child health problem in our setting. Most acute cough is due to upper respiratory tract infection (URTI) [25]. Even though URTI is associated with low mortality, it significantly disturbs children's daily activities such as sleeping and eating and may cause school absence and parent work absence [26]. A previous study assessing the effect of acute cough on child HRQOL using the Parent-proxy Children's Acute Cough-specific QoL (PAC-QoL) Questionnaire found that children who suffered acute cough have lower HRQOL across all domains [27]. 
We found that perinatal factors, namely LBW and abnormal delivery, lower the child's HRQOL based on proxy-reports. This result was similar to a review study assessing the impact of preterm and LBW on HRQOL of preschool- and school-aged children, adolescents, and young adults. The review found that the history of prematurity and LBW lower the HRQOL at various age groups. The effect of LBW and gestational age is greatest during the younger period, but the effect extended into adulthood [28]. Our finding is quite essential since LBW is still a significant public health problem. In 2015, an estimated 20.5 million live births were LBW, 91\% from low-middle income countries, mainly southern Asia (48\%) and sub-Saharan Africa (24\%) [29]. The prevalence of LBW in our study population was $5.6 \%$ (self-reported) and $6.0 \%$ (proxy-reported), similar to the prevalence of LBW reported by Indonesian Basic Health Research 2018 , which was $6.2 \%$ [10]. LBW has been identified as a risk of adverse outcomes other than infant mortality-morbidity, including impaired neurodevelopment outcome at school-age and non-communicable diseases later in life [30]. A systematic review and meta-analysis studies on the impact of LBW on South Asian children found that children who were born LBW have significant impairment on cognitive and motor function [31]. Our study provides an additional value to use HRQOL assessment, a simple but valid and reliable tool, to detect the impact of perinatal problems on the whole aspect of health in the preschool to adolescence period. Our finding also emphasized the importance of preventing LBW.

Strengths and limitations

This study has some limitations. This study was a cross-sectional study; therefore, the results only support an association between determinant variables and HRQOL, not causality. In addition, other determinants were not assessed, and thus further research is needed. We also did not consider the school environment. A study in urban schoolchildren found that children's perception of closeness to school personnel and the school environment and "school connectedness' were significantly related to the HRQOL [21]. We excluded children who have been diagnosed with chronic health problems, mental and behavioral health problems. However, a cluster sampling approach using the Health and Demographic Surveillance System (HDSS) sample frame makes this study represent HRQOL of "healthy" children in the semi-urban city of Indonesia. Including acute health complaints and LBW, common health problems in developing countries, as determinants of children's HRQOL, support the importance of health promotion and prevention. Using both proxy-reports and self-reports is also the strength of the study. We found there was a fair to moderate agreement between self-reports and proxy reports. Self-report is considered the standard for measuring HRQOL, because it is more likely to accurately represent internal measures of health than the proxy reporting. However, parent proxy-report should be considered as a secondary measure contributed to health-seeking behavior or health care usage.

\section{Conclusions}

In addition to sociodemographic determinants of child's HRQOL, children with acute health problems and LBW have a lower HRQOL in the general pediatric population. In low- and middle-income countries where acute infections and LBW are still prevalent, its prevention and appropriate interventions should improve child health. 


\section{Abbreviations}

HRQOL: health-related quality of life

Peds QL ${ }^{\mathrm{TM}}$ : Pediatric Quality of life Inventory ${ }^{\mathrm{TM}}$

WHO: World Health Organization

HDSS: The Health and Demographic Surveillance System

LBW: Low birth weight

SPSS: Statistical Package for the Social Sciences

ICC: Inter-Class Correlation

URTI: Upper respiratory tract infection

PAC-QoL: Parent-proxy Children's Acute Cough-specific QoL

\section{Declarations}

\section{Ethics approval}

Ethical approval was obtained from the Medical and Health Research Ethics Committee of the Faculty of Medicine, Public Health and Nursing, Universitas Gadjah Mada, Yogyakarta, Indonesia.

\section{Consent to participate}

Written informed consent was obtained from all parents/guardians of the children 2-18 years, and assent of 11-18 years old children.

\section{Consent for publication}

This article has not been previously published and is not currently under consideration by any other journal. All authors have approved the content of this paper and have agreed to the submission policies.

\section{Availability of data and material}

The datasets that support the conclusions of this article are available by request to the corresponding author. We do not make participants' data publicly available due to data protection restrictions and participant confidentiality.

\section{Competing interest}

We declared that all authors have no competing interests to declare. 


\section{Funding}

This research was funded by Universitas Gadjah Mada.

\section{Authors' contributions}

MNS, BWI, NWR and AW share the responsibility to develop the study design. MNS, BWI and NMR were responsible in collecting the data. MNS and AW performed data analysis. MNS and ZS have drafted the manuscript. All authors have read and approved the final manuscript.

\section{Acknowledgements}

We would like to thank to the Sleman Health and Demographic Surveillance System (HDSS) team for their support in collecting the data.

\section{References}

1. Solans M, Pane S, Estrada MD, Serra-Sutton V, Berra S, Herdman M, Alonso J, Rajmil L. Health-related quality of life measurement in children and adolescents: a systematic review of generic and diseasespecific instruments. Value Health. 2008;11(4):742-64.

2. Simon AE, Chan KS, Forrest CB. Assessment of children's health-related quality of life in the United States with a multidimensional index. Pediatrics. 2008;121(1):e118-26.

3. DeSalvo KB, Bloser N, Reynolds K, He J, Muntner P. Mortality prediction with a single general selfrated health question. A meta-analysis. J Gen Intern Med. 2006;21(3):267-75.

4. Ravens-Sieberer U, Herdman M, Devine J, Otto C, Bullinger M, Rose M, Klasen F. The European KIDSCREEN approach to measure quality of life and well-being in children: development, current application, and future advances. Qual Life Res. 2014;23(3):791-803.

5. Houben-van Herten M, Bai G, Hafkamp E, Landgraf JM, Raat $\mathrm{H}$. Determinants of health-related quality of life in school-aged children: a general population study in the Netherlands. PLoS One. 2015;10(5):e0125083.

6. Waters E, Davis E, Nicolas C, Wake M, Lo SK. The impact of childhood conditions and concurrent morbidities on child health and well-being. Child Care Health Dev. 2008;34(4):418-29.

7. Wilkins AJ, O'Callaghan MJ, Najman JM, Bor W, Williams GM, Shuttlewood G. Early childhood factors influencing health-related quality of life in adolescents at 13 years. J Paediatr Child Health. 2004;40(3):102-9.

8. Eiser C, Morse R. Can parents rate their child's health-related quality of life? Results of a systematic review. Qual Life Res. 2001;10(4):347-57.

9. Liu W, Lin R, Liu W, Guo Z, Xiong L, Li B, Cheng KK, Adab P, Pallan M. Relationship between weight status and health-related quality of life in Chinese primary school children in Guangzhou: a crosssectional study. Health Qual Life Outcomes. 2016;14(1):166. 
10. Agency of Health Research and Development (Indonesia). Indonesia Basic Health Research (RISKESDAS). 2018. http://ghdx.healthdata.org/record/indonesia-basic-health-research-2018. Accessed 16 May 2021.

11. Dewi FST, Choiriyyah I, Indriyani C, Wahab A, Lazuardi L, Nugroho A, Susetyowati S, Harisaputra RK, Santi R, Lestari SK, Ng N, Hakimi M, Josef HK, Utarini A. Designing and collecting data for a longitudinal study: the Sleman Health and Demographic Surveillance System (HDSS). Scand J Public Health. 2018;46(7):704-710.

12. Sitaresmi MN, Mostert S, Gundy CM, Sutaryo, Veerman AJ. Health-related quality of life assessment in Indonesian childhood acute lymphoblastic leukemia. Health Qual Life Outcomes. 2008;6:96.

13. Varni JW, Seid M, Kurtin PS. PedsQL 4.0: reliability and validity of the Pediatric Quality of Life Inventory version 4.0 generic core scales in healthy and patient populations. Med Care. 2001;39(8):800-12.

14. Desai AD, Zhou C, Stanford S, Haaland W, Varni JW, Mangione-Smith RM. Validity and responsiveness of the pediatric quality of life inventory (PedsQL) 4.0 generic core scales in the pediatric inpatient setting. JAMA Pediatr. 2014;168(12):1114-21.

15. Varni JW, Burwinkle TM, Seid M, Skarr D. The PedsQL 4.0 as a pediatric population health measure: feasibility, reliability, and validity. Ambul Pediatr. 2003;3(6):329-41.

16. Raj M, Sudhakar A, Roy R, Champaneri B, Joy TM, Kumar RK. Health-related quality of life in Indian children: A community-based cross-sectional survey. Indian J Med Res. 2017;145(4):521-529.

17. The World Health Organization Quality of Life assessment (WHOQOL): position paper from the World Health Organization. Soc Sci Med. 1995;41(10):1403-9.

18. Sarria EE, Mundstock E, Machado DG, Mocelin HT, Fischer GB, Furlan SP, Antonello ICF, Stein R, Mattiello R. Health-related quality of life in patients with bronchiolitis obliterans. J Pediatr (Rio J). 2018;94(4):374-379.

19. Didsbury MS, Kim S, Medway MM, Tong A, McTaggart SJ, Walker AM, White S, Mackie FE, Kara T, Craig JC, Wong G. Socio-economic status and quality of life in children with chronic disease: A systematic review. J Paediatr Child Health. 2016;52(12):1062-1069.

20. Fachrunnisa, R. 2020. Education of Indonesian Girls: The Outlook of Discrimination, Rights, and the Impact on Society. KnE Social Sciences. 2020;4(10):349-359

21. Mansour ME, Kotagal U, Rose B, Ho M, Brewer D, Roy-Chaudhury A, Hornung RW, Wade TJ, DeWitt TG. Health-related quality of life in urban elementary schoolchildren. Pediatrics. 2003;111(6 Pt 1):137281.

22. OECD. Social Protection System Review of Indonesia, OECD Development Pathways, OECD. 2019. https://www.oecd.org/social/inclusivesocietiesanddevelopment/SPSR_Indonesia_ebook.pdf. Accessed 18 May 2021.

23. Institute of Medicine (US) Committee on the Consequences of Uninsurance. Care Without Coverage: Too Little, Too Late. Washington (DC): National Academies Press (US); 2002. 
24. Meyer M, Oberhoffer R, Hock J, Giegerich T, Müller J. Health-related quality of life in children and adolescents: Current normative data, determinants and reliability on proxy-report. J Paediatr Child Health. 2016;52(6):628-31.

25. Marseglia GL, Manti S, Chiappini E, Brambilla I, Caffarelli C, Calvani M, Cardinale F, Cravidi C, Duse M, Martelli A, Minasi D, Del Giudice MM, Pajno G, Peroni DG, Tosca MA, Licari A, Ciprandi G. Acute cough in children and adolescents: A systematic review and a practical algorithm by the Italian Society of Pediatric Allergy and Immunology. Allergol Immunopathol (Madr). 2021;49(2):155-169.

26. Schot MJC, Dekker ARJ, van Werkhoven CH, van der Velden AW, Cals JWL, Broekhuizen BDL, Hopstaken RM, de Wit NJ, Verheij TJM. Burden of disease in children with respiratory tract infections in primary care: diary-based cohort study. Fam Pract. 2019;36(6):723-729.

27. Musaad, A., Aldayel, A., Sulieman, M., et al. Quality of life of children with acute cough: a crosssectional study. International Journal of Medicine in Developing Countries. 2020; 4(12): 2149-2152

28. Zwicker JG, Harris SR. Quality of life of formerly preterm and very low birth weight infants from preschool age to adulthood: a systematic review. Pediatrics. 2008;121(2):e366-76.

29. Blencowe H, Krasevec J, de Onis M, Black RE, An X, Stevens GA, Borghi E, Hayashi C, Estevez D, Cegolon L, Shiekh S, Ponce Hardy V, Lawn JE, Cousens S. National, regional, and worldwide estimates of low birthweight in 2015, with trends from 2000: a systematic analysis. Lancet Glob Health. 2019;7(7):e849-e860.

30. World Health Organization. Global nutrition targets 2025: low birth weight policy brief. World Health Organization. 2014. https://apps.who.int/iris/handle/10665/149020. Accessed 18 May 2021.

31. Upadhyay RP, Naik G, Choudhary TS, Chowdhury R, Taneja S, Bhandari N, Martines JC, Bahl R, Bhan MK. Cognitive and motor outcomes in children born low birth weight: a systematic review and metaanalysis of studies from South Asia. BMC Pediatr. 2019;19(1):35.

\section{Tables}


Table 1

General Characteristic of Respondents

\begin{tabular}{|c|c|c|}
\hline Variable & Child self-reports & Proxy-reports \\
\hline & $(n=531)$ & $(n=633)$ \\
\hline & $\mathrm{n}(\%)$ & $\mathrm{n}(\%)$ \\
\hline \multicolumn{3}{|l|}{ Respondent status } \\
\hline Fathers & $133(24.40)$ & $143(22.59)$ \\
\hline Mothers & $357(65.50)$ & $420(66.35)$ \\
\hline Other caregivers & $55(10.09)$ & $70(11.06)$ \\
\hline Child age in year, mean (SD) & $11.5(3.9)$ & $10.4(4.7)$ \\
\hline 2-12 year-group & $300(56.50)$ & $396(62.56)$ \\
\hline 13-18 year-group & $231(43.50)$ & $237(37.44)$ \\
\hline \multicolumn{3}{|l|}{ Child gender } \\
\hline Male & $281(52.92)$ & $328(51.82)$ \\
\hline Female & $250(47.08)$ & $305(48.18)$ \\
\hline \multicolumn{3}{|l|}{ Number of child in family } \\
\hline 1 & $82(15.44)$ & $111(17.54)$ \\
\hline 2 & $266(50.09)$ & $311(49.13)$ \\
\hline$\geq 3$ & $183(34.46)$ & $211(33.33)$ \\
\hline \multicolumn{3}{|l|}{ Order of the child in family } \\
\hline 1st child & $231(43.50)$ & $270(42.65)$ \\
\hline 2nd or more & $300(56.50)$ & $363(57.35)$ \\
\hline \multicolumn{3}{|l|}{ Birth weight } \\
\hline$\geq 2,500$ gram & $480(90.40)$ & $574(90.68)$ \\
\hline$<2,500$ gram & $30(5.65)$ & $38(6.00)$ \\
\hline Unknown & $21(3.95)$ & $21(3.32)$ \\
\hline \multicolumn{3}{|l|}{ Mode of delivery } \\
\hline Normal & $455(85.69)$ & $528(83.41)$ \\
\hline SC & 75 (14.12) & $104(16.43)$ \\
\hline Unknown & $1(0.19)$ & $1(0.16)$ \\
\hline
\end{tabular}




\begin{tabular}{|c|c|c|}
\hline \multicolumn{3}{|l|}{ History of illness in the past 1 month } \\
\hline Yes & $237(44.63)$ & $313(49.45)$ \\
\hline No & $294(55.37)$ & $320(50.55)$ \\
\hline \multicolumn{3}{|l|}{ Location } \\
\hline Urban & $458(86.25)$ & $549(86.73)$ \\
\hline Rural & 73 (13.75) & $84(13.27)$ \\
\hline \multicolumn{3}{|l|}{ Fathers' educational level } \\
\hline Basic education (< 12 years education) & $173(32.58)$ & $195(30.81)$ \\
\hline Higher education ( $\geq 12$ years education) & $358(67.42)$ & $438(69.19)$ \\
\hline \multicolumn{3}{|l|}{ Mothers' educational level } \\
\hline Basic education (< 12 years education) & $169(31.83)$ & $195(30.81)$ \\
\hline Higher education (>12 years education) & $362(68.17)$ & $438(69.19)$ \\
\hline \multicolumn{3}{|l|}{ Working situation parents } \\
\hline both parents work & $259(46.75)$ & $285(45.02)$ \\
\hline one parent work & $283(51.08)$ & $336(53.08)$ \\
\hline both parents do not work & $12(2.17)$ & $12(1.90)$ \\
\hline \multicolumn{3}{|l|}{ Insurance } \\
\hline Paid by government & $245(44.87)$ & $283(44.71)$ \\
\hline self- funded & $223(40.84)$ & $262(41.39)$ \\
\hline do not have Insurance & 78 (14.29) & $88(13.90)$ \\
\hline
\end{tabular}


Table 2

Inter Class Correlation between self-report and proxy-report

\begin{tabular}{|lllll|}
\hline Scale descriptive & Child self-reports & Proxy-reports & ICC & $p$ \\
\hline Total sample $(\mathbf{n})$ & 531 & Mean (SD) & & \\
\hline Total score & $89.28(8.92)$ & $92.90(6.73)$ & 0.49 & 0.000 \\
\hline Physical health & $94.24(7.65)$ & $96.35(6.27)$ & 0.45 & 0.000 \\
\hline Psychosocial health & $87.63(10.30)$ & $91.71(8.02)$ & 0.48 & 0.000 \\
\hline Emotional functioning & $85.19(15.39)$ & $89.24(12.07)$ & 0.41 & 0.000 \\
\hline Social functioning & $93.14(10.873)$ & $96.49(7.65)$ & 0.38 & 0.000 \\
\hline School functioning & $84.39(13.80)$ & $89.35(11.56)$ & 0.48 & 0.000 \\
\hline
\end{tabular}

SD, standard deviation. 
Table 3

Bivariate analysis of health-related quality of life's determinants based on child report

\begin{tabular}{|lllllll}
$\begin{array}{l}\text { Scale } \\
\text { Description }\end{array}$ & $\begin{array}{l}\text { Total } \\
\text { score }\end{array}$ & $\begin{array}{l}\text { Physical } \\
\text { health }\end{array}$ & $\begin{array}{l}\text { Psychosocial } \\
\text { health }\end{array}$ & $\begin{array}{l}\text { Emotional } \\
\text { functioning }\end{array}$ & $\begin{array}{l}\text { Social } \\
\text { Functioning }\end{array}$ & $\begin{array}{l}\text { School } \\
\text { Functioning }\end{array}$ \\
& $\begin{array}{l}\text { Mean } \\
\text { (SD) }\end{array}$ & $\begin{array}{l}\text { Mean } \\
\text { (SD) }\end{array}$ & Mean (SD) & Mean (SD) & Mean (SD) & Mean (SD) \\
& & & & & \\
\end{tabular}

\section{Age Group}

$\begin{array}{lllllll}\begin{array}{l}\text { Children group } \\ \begin{array}{l}2-12 \text { Years) } \\ (n=300)\end{array}\end{array} & \begin{array}{l}88.95 \\ (9.08)\end{array} & \begin{array}{l}94.29 \\ (7.67)\end{array} & \begin{array}{l}87.19 \\ (10.62)\end{array} & \begin{array}{l}84.20 \\ (15.85)^{\star *}\end{array} & \begin{array}{l}92.38 \\ (11.69)^{\star}\end{array} & \begin{array}{l}85.00 \\ (14.54)\end{array} \\ \begin{array}{l}\text { Adolescence } \\ \text { group }(13-18\end{array} & \begin{array}{l}89.71 \\ \text { Years) (n=231) }\end{array} & \begin{array}{l}94.70) \\ (7.65)\end{array} & 88.21(9.87) & \begin{array}{l}86.47 \\ (14.71)\end{array} & \begin{array}{l}94.11 \\ (9.64)\end{array} & \begin{array}{l}83.55 \\ (12.71)\end{array}\end{array}$

\section{Child gender}

\begin{tabular}{lllllll} 
Male $(\mathrm{n}=281)$ & 89.39 & 94.55 & 87.65 & 86.10 & 93.10 & 83.46 \\
& $(8.71)$ & $(6.35)$ & $(10.40)$ & $(15.33)$ & $(10.78)$ & $(13.71)$ \\
\hline Female $(\mathrm{n}=250)$ & $\begin{array}{l}89.16 \\
(9.16)\end{array}$ & $\begin{array}{l}93.89 \\
(8.88)\end{array}$ & $\begin{array}{l}87.60 \\
(10.21)\end{array}$ & $\begin{array}{l}84.16 \\
(15.43)\end{array}$ & $\begin{array}{l}93.18 \\
(11.00)\end{array}$ & $\begin{array}{l}85.41 \\
(13.85)\end{array}$
\end{tabular}

\section{Number of children in family}

$\begin{array}{lllllll}2(\mathrm{n}=348) & 89.87 & 94.63 & 88.29(9.54)^{*} & 86.05 & 93.38 & 85.31 \\ & (8.17)^{*} & (7.04) & & (14.33) & (9.87) & (13.05)^{*} \\ \geq 3(183) & 88.17 & 93.49 & 86.38 & 83.55 & 92.68 & 82.61 \\ & (10.12) & (8.65) & (11.53) & (17.15) & (12.58) & (15.02)\end{array}$

\section{Position of child in family}

$\begin{array}{lllllll}\begin{array}{l}\text { 1st child } \\ (\mathrm{n}=231)\end{array} & \begin{array}{l}90.31 \\ (7.48)^{*}\end{array} & \begin{array}{l}94.80 \\ (6.56)\end{array} & 88.82(8.71)^{*} & \begin{array}{l}86.13 \\ (14.36)\end{array} & \begin{array}{l}94.33 \\ (8.72)^{*}\end{array} & \begin{array}{l}85.84 \\ (12.22)^{*}\end{array} \\ \begin{array}{llllll}\text { 2nd or more } \\ (\mathrm{n}=300)\end{array} & \begin{array}{l}88.12 \\ (10.00)\end{array} & \begin{array}{l}93.67 \\ (8.29)\end{array} & \begin{array}{l}86.27 \\ (11.58)\end{array} & \begin{array}{l}83.89 \\ (16.59)\end{array} & \begin{array}{l}91.55 \\ (13.00)\end{array} & \begin{array}{l}83.38 \\ (14.68)\end{array}\end{array}$

\section{Birth weight}

$\begin{array}{lllllll}<2,500 \text { grams } & 86.73 & 92.08 & 84.94 & 82.17 & 91.33 & 80.86 \\ (\mathrm{n}=30) & (10.05) & (9.38) & (10.84) & (15.69) & (12.38) & (12.68) \\ \geq 2,500 \text { grams } & 89.34 & 94.29 & 87.69 & 85.20 & 93.20 & 84.51 \\ (\mathrm{n}=480) & (8.89) & (7.64) & (10.30) & (15.45) & (10.83) & (13.90)\end{array}$

\section{Mode of delivery}

$\begin{array}{lllllll}\text { Normal }(\mathrm{n}=455) & 89.44 & 94.48 & 87.76 & 85.27 & 93.18 & 84.65 \\ & (8.90) & (7.49) & (10.33) & (15.55) & (10.97) & (13.83)\end{array}$




\begin{tabular}{|c|c|c|c|c|c|c|}
\hline$S C(n=75)$ & $\begin{array}{l}88.21 \\
(9.02)\end{array}$ & $\begin{array}{l}92.71 \\
(8.48)\end{array}$ & $\begin{array}{l}86.71 \\
(10.18)\end{array}$ & $\begin{array}{l}84.47 \\
(14.49)\end{array}$ & $\begin{array}{l}92.80 \\
(10.41)\end{array}$ & $\begin{array}{l}82.67 \\
(13.64)\end{array}$ \\
\hline \multicolumn{7}{|l|}{$\begin{array}{l}\text { History of } \\
\text { illness in the } \\
\text { past } 1 \text { month }\end{array}$} \\
\hline Yes $(n=237)$ & $\begin{array}{l}87.50 \\
(9.22)^{\star \star}\end{array}$ & $\begin{array}{l}92.76 \\
(8.09)^{\star \star}\end{array}$ & $\begin{array}{l}85.75 \\
(10.75)^{\star \star}\end{array}$ & $\begin{array}{l}83.48 \\
(16.23)^{\star}\end{array}$ & $\begin{array}{l}92.09 \\
(11.37)^{*}\end{array}$ & $\begin{array}{l}81.59 \\
(14.24)^{\star \star}\end{array}$ \\
\hline No $(n=294)$ & $\begin{array}{l}90.72 \\
(8.41)\end{array}$ & $\begin{array}{l}95.43 \\
(7.06)\end{array}$ & 89.15 (9.68) & $\begin{array}{l}86.56 \\
(14.56)\end{array}$ & $\begin{array}{l}93.98 \\
(10.40)\end{array}$ & $\begin{array}{l}86.65 \\
(13.02)\end{array}$ \\
\hline \multicolumn{7}{|l|}{ Location } \\
\hline Urban $(n=458)$ & $\begin{array}{l}89.02 \\
(8.99)\end{array}$ & $\begin{array}{l}94.10 \\
(7.72)\end{array}$ & $\begin{array}{l}87.32 \\
(10.37)\end{array}$ & $\begin{array}{l}84.88 \\
(15.36)\end{array}$ & $\begin{array}{l}92.97 \\
(10.84)\end{array}$ & $\begin{array}{l}84.04 \\
(14.09)\end{array}$ \\
\hline Rural $(n=73)$ & $\begin{array}{l}90.95 \\
(8.31)\end{array}$ & $\begin{array}{l}95.08 \\
(7.22)\end{array}$ & 89.58 (9.72) & $\begin{array}{l}87.12 \\
(15.52)\end{array}$ & $\begin{array}{l}94.18 \\
(11.09)\end{array}$ & $\begin{array}{l}86.69 \\
(11.51)\end{array}$ \\
\hline \multicolumn{7}{|l|}{$\begin{array}{l}\text { Fathers' } \\
\text { educational } \\
\text { level }\end{array}$} \\
\hline $\begin{array}{l}\text { Basic education } \\
(n=173)\end{array}$ & $\begin{array}{l}88.19 \\
(9.81)\end{array}$ & $\begin{array}{l}93.42 \\
(8.78)\end{array}$ & $\begin{array}{l}86.45 \\
(11.19)\end{array}$ & $\begin{array}{l}85.61 \\
(15.25)\end{array}$ & $\begin{array}{l}91.47 \\
(12.85)^{*}\end{array}$ & $\begin{array}{l}81.79 \\
(14.35)^{\star \star}\end{array}$ \\
\hline $\begin{array}{l}\text { Higher } \\
\text { education } \\
(n=358)\end{array}$ & $\begin{array}{l}89.81 \\
(8.41)\end{array}$ & $\begin{array}{l}94.63 \\
(7.02)\end{array}$ & $88.20(9.81)$ & $\begin{array}{l}84.99 \\
(15.47)\end{array}$ & $\begin{array}{l}93.94 \\
(9.69)\end{array}$ & $\begin{array}{l}85.61 \\
(13.38)\end{array}$ \\
\hline \multicolumn{7}{|l|}{$\begin{array}{l}\text { Mothers' } \\
\text { educational } \\
\text { level }\end{array}$} \\
\hline $\begin{array}{l}\text { Basic education } \\
(n=169)\end{array}$ & $\begin{array}{l}89.17 \\
(9.05)\end{array}$ & $\begin{array}{l}94.12 \\
(8.28)\end{array}$ & $\begin{array}{l}87.56 \\
(10.24)\end{array}$ & $\begin{array}{l}86.33 \\
(14.43)\end{array}$ & $\begin{array}{l}92.04 \\
(12.08)\end{array}$ & $\begin{array}{l}83.62 \\
(14.34)\end{array}$ \\
\hline $\begin{array}{l}\text { Higher } \\
\text { education } \\
(n=362)\end{array}$ & $\begin{array}{l}89.33 \\
(8.87)\end{array}$ & $\begin{array}{l}94.29 \\
(7.35)\end{array}$ & $\begin{array}{l}87.66 \\
(10.34)\end{array}$ & $\begin{array}{l}84.65 \\
(15.81)\end{array}$ & $\begin{array}{l}93.65 \\
(10.24)\end{array}$ & $\begin{array}{l}84.73 \\
(13.56)\end{array}$ \\
\hline \multicolumn{7}{|l|}{ Working parents } \\
\hline Both $(n=245)$ & $\begin{array}{l}90.08 \\
(8.47)\end{array}$ & $\begin{array}{l}95.00 \\
(6.90)^{\star}\end{array}$ & $88.43(9.82)$ & $\begin{array}{l}86.29 \\
(14.99)\end{array}$ & $\begin{array}{l}93.57 \\
(10.25)\end{array}$ & $\begin{array}{l}85.27 \\
(12.84)\end{array}$ \\
\hline $\begin{array}{l}\text { One or none } \\
(n=286)\end{array}$ & $\begin{array}{l}88.60 \\
(9.24)\end{array}$ & $\begin{array}{l}93.59 \\
(8.20)\end{array}$ & $\begin{array}{l}86.95 \\
(10.67)\end{array}$ & $\begin{array}{l}84.25 \\
(15.69)\end{array}$ & $\begin{array}{l}92.76 \\
(11.38)\end{array}$ & $\begin{array}{l}83.63 \\
(14.56)\end{array}$ \\
\hline \multicolumn{7}{|l|}{ Insurance } \\
\hline $\begin{array}{l}\text { Paid by } \\
\text { government or } \\
\text { have no } \\
\text { insurance } \\
(n=317)\end{array}$ & $\begin{array}{l}88.78 \\
(9.36)\end{array}$ & $\begin{array}{l}93.57 \\
(7.96)^{\star}\end{array}$ & $\begin{array}{l}87.17 \\
(10.83)\end{array}$ & $\begin{array}{l}84.53 \\
(16.60)\end{array}$ & $\begin{array}{l}92.95 \\
(10.84)\end{array}$ & $\begin{array}{l}83.88 \\
(14.07)\end{array}$ \\
\hline
\end{tabular}




$\begin{array}{lllllll}\text { Self-funding } & 90.03 & 95.22 & 88.32(9.45) & 86.17 & 93.41 & 85.14 \\ (\mathrm{n}=214) & (8.17) & (7.07) & & (13.39) & (10.94) & (13.40)\end{array}$

${ }^{*} p<0.05 * * p<0.01 ; \mathrm{SD}$, standard deviation;

Analysis using Independent -sample T-test 
Table 4

Bivariate analysis of health-related quality of life's determinants based on proxy-report

\begin{tabular}{|c|c|c|c|c|c|c|}
\hline Variable & $\begin{array}{l}\text { Total } \\
\text { score }\end{array}$ & $\begin{array}{l}\text { Physical } \\
\text { Functioning }\end{array}$ & $\begin{array}{l}\text { Psychosocial } \\
\text { Functioning }\end{array}$ & $\begin{array}{l}\text { Emotional } \\
\text { Functioning }\end{array}$ & $\begin{array}{l}\text { Social } \\
\text { Functioning }\end{array}$ & $\begin{array}{l}\text { School } \\
\text { Functioning }\end{array}$ \\
\hline & $\begin{array}{l}\text { Mean } \\
\text { (SD) }\end{array}$ & Mean (SD) & Mean (SD) & Mean (SD) & Mean (SD) & Mean (SD) \\
\hline \multicolumn{7}{|l|}{ Age } \\
\hline $\begin{array}{l}\text { Children (2- } \\
12 \text { Years) } \\
(\mathrm{n}=268)\end{array}$ & $\begin{array}{l}91.77 \\
(7.42) \star \star\end{array}$ & $\begin{array}{l}96.05 \\
(6.84)^{\star}\end{array}$ & $\begin{array}{l}90.29 \\
(8.89) \star \star\end{array}$ & $\begin{array}{l}87.50 \\
(12.90)^{\star \star}\end{array}$ & $\begin{array}{l}95.04 \\
(9.03)^{\star \star}\end{array}$ & $\begin{array}{l}88.34 \\
(12.68)\end{array}$ \\
\hline $\begin{array}{l}\text { Adolescence } \\
(13-18 \\
\text { Years) } \\
(n=365)\end{array}$ & $\begin{array}{l}94.78 \\
(4.82)\end{array}$ & $\begin{array}{l}96.86 \\
(5.16)\end{array}$ & $94.10(5.58)$ & $\begin{array}{l}92.15 \\
(9.90)\end{array}$ & $\begin{array}{l}98.90 \\
(3.30)\end{array}$ & $\begin{array}{l}90.97 \\
(9.28)\end{array}$ \\
\hline \multicolumn{7}{|l|}{ Child gender } \\
\hline $\begin{array}{l}\text { Male } \\
(n=328)\end{array}$ & $\begin{array}{l}92.86 \\
(6.57)\end{array}$ & $\begin{array}{l}96.78 \\
(5.00)\end{array}$ & $91.50(7.88)$ & $\begin{array}{l}89.18 \\
(12.27)\end{array}$ & $\begin{array}{l}96.89 \\
(7.12)\end{array}$ & $\begin{array}{l}88.29 \\
(12.18)^{*}\end{array}$ \\
\hline $\begin{array}{l}\text { Female } \\
(\mathrm{n}=305)\end{array}$ & $\begin{array}{l}92.94 \\
(6.90)\end{array}$ & $\begin{array}{l}95.89 \\
(7.38)\end{array}$ & $91.94(8.18)$ & $\begin{array}{l}89.31 \\
(11.88)\end{array}$ & $\begin{array}{l}96.05 \\
(8.16)\end{array}$ & $\begin{array}{l}90.46 \\
(10.78)\end{array}$ \\
\hline \multicolumn{7}{|l|}{$\begin{array}{l}\text { Number of } \\
\text { children in } \\
\text { family }\end{array}$} \\
\hline$<=2(n=422)$ & $\begin{array}{l}92.76 \\
(7.11)\end{array}$ & $\begin{array}{l}96.25 \\
(6.70)\end{array}$ & $91.56(8.44)$ & $\begin{array}{l}89.18 \\
(12.54)\end{array}$ & $\begin{array}{l}96.40 \\
(7.59)\end{array}$ & $\begin{array}{l}89.15 \\
(11.90)\end{array}$ \\
\hline$>2(n=211)$ & $\begin{array}{l}93.17 \\
(5.90)\end{array}$ & $\begin{array}{l}96.55 \\
(5.31)\end{array}$ & $92.02(7.12)$ & $\begin{array}{l}89.36 \\
(11.10)\end{array}$ & $\begin{array}{l}96.66 \\
(7.77)\end{array}$ & $\begin{array}{l}89.75 \\
(10.86)\end{array}$ \\
\hline \multicolumn{7}{|l|}{$\begin{array}{l}\text { Child } \\
\text { position in } \\
\text { family }\end{array}$} \\
\hline $\begin{array}{l}\text { 1st child } \\
(n=270)\end{array}$ & $\begin{array}{l}92.92 \\
(6.97)\end{array}$ & $\begin{array}{l}96.28 \\
(6.14)\end{array}$ & 91.77 (8.22) & $\begin{array}{l}89.07 \\
(12.80)\end{array}$ & $\begin{array}{l}96.70 \\
(7.43)\end{array}$ & $\begin{array}{l}89.60 \\
(10.88)\end{array}$ \\
\hline $\begin{array}{l}\text { 2nd or more } \\
(n=363)\end{array}$ & $\begin{array}{l}92.88 \\
(6.55)\end{array}$ & $\begin{array}{l}96.40 \\
(6.38)\end{array}$ & $91.67(7.88)$ & $\begin{array}{l}89.37 \\
(11.52)\end{array}$ & $\begin{array}{l}96.32 \\
(7.81)\end{array}$ & $\begin{array}{l}89.15 \\
(12.08)\end{array}$ \\
\hline \multicolumn{7}{|l|}{ Birth weight } \\
\hline $\begin{array}{l}<2,500 \\
\text { grams } \\
(n=38)\end{array}$ & $\begin{array}{l}90.49 \\
(8.55)^{\star}\end{array}$ & $\begin{array}{l}94.74 \\
(6.70)\end{array}$ & $\begin{array}{l}89.09 \\
(10.44)^{\star}\end{array}$ & $\begin{array}{l}83.82 \\
(17.02) \star \star\end{array}$ & $\begin{array}{l}95.00 \\
(9.72)\end{array}$ & $\begin{array}{l}87.96 \\
(11.94)\end{array}$ \\
\hline $\begin{array}{l}\geq 2,500 \\
\text { grams } \\
(n=574)\end{array}$ & $\begin{array}{l}93.02 \\
(6.56)\end{array}$ & $\begin{array}{l}96.39 \\
(6.32)\end{array}$ & $91.86(7.77)$ & $\begin{array}{l}89.53 \\
(11.65)\end{array}$ & $\begin{array}{l}96.59 \\
(7.43)\end{array}$ & $\begin{array}{l}89.44 \\
(11.45)\end{array}$ \\
\hline
\end{tabular}




\begin{tabular}{lllllll}
$\begin{array}{l}\text { Normal } \\
(n=528)\end{array}$ & $\begin{array}{l}93.20 \\
(6.58) \star \star\end{array}$ & $\begin{array}{l}96.49 \\
(6.48)\end{array}$ & $\begin{array}{l}92.10 \\
(7.70) \star \star\end{array}$ & $\begin{array}{l}89.74 \\
(11.50) *\end{array}$ & $\begin{array}{l}96.76 \\
(7.39) *\end{array}$ & $\begin{array}{l}89.61 \\
(11.37)\end{array}$ \\
\hline SC $(n=104)$ & $\begin{array}{l}91.33 \\
(7.25)\end{array}$ & $\begin{array}{l}95.64 \\
(5.10)\end{array}$ & $89.72(9.29)$ & 86.68 & 95.05 & 87.73 \\
& & & $(14.51)$ & $(8.77)$ & $(12.54)$
\end{tabular}

\section{History of \\ illness in the \\ past 1 \\ month}

$\begin{array}{lllllll}\text { Yes }(n=313) & \begin{array}{l}91.02 \\ (7.43)^{\star \star}\end{array} & \begin{array}{l}94.95 \\ (7.34)^{\star \star}\end{array} & \begin{array}{l}89.67 \\ (8.72)^{\star \star}\end{array} & \begin{array}{l}86.44 \\ (13.27)^{\star \star}\end{array} & \begin{array}{l}95.42 \\ (8.55)^{\star \star}\end{array} & \begin{array}{l}87.01 \\ (12.59)^{\star \star}\end{array} \\ \text { No }(n=320) & 94.73 & 97.72 & 93.71(6.71) & 91.98 & 97.53 & 91.57 \\ & (5.36) & (4.63) & & (10.07) & (6.49) & (10.02)\end{array}$

\section{Location}

\begin{tabular}{lllllll}
$\begin{array}{l}\text { Urban } \\
(\mathrm{n}=549)\end{array}$ & $\begin{array}{l}92.84 \\
(6.81)\end{array}$ & $\begin{array}{l}96.37 \\
(6.39)\end{array}$ & $91.63(8.10)$ & $\begin{array}{l}89.14 \\
(11.97)\end{array}$ & $\begin{array}{l}96.47 \\
(7.82)\end{array}$ & $\begin{array}{l}89.29 \\
(11.67)\end{array}$ \\
\hline Rural $(\mathrm{n}=84)$ & $\begin{array}{l}93.28 \\
(6.19)\end{array}$ & $\begin{array}{l}96.21 \\
(5.43)\end{array}$ & $92.24(7.51)$ & $\begin{array}{l}89.88 \\
(12.82)\end{array}$ & $\begin{array}{l}96.61 \\
(6.41)\end{array}$ & $\begin{array}{l}89.80 \\
(10.88)\end{array}$
\end{tabular}

\section{Fathers' educational level}

\begin{tabular}{lllllll}
$\begin{array}{l}\text { Basic } \\
\text { education } \\
(n=195)\end{array}$ & $\begin{array}{l}91.83 \\
(7.31)^{\star \star}\end{array}$ & $\begin{array}{l}95.66 \\
(7.40)\end{array}$ & $90.55(8.78)^{\star}$ & $\begin{array}{l}87.90 \\
(13.36)\end{array}$ & $\begin{array}{l}96.08 \\
(8.74)\end{array}$ & $\begin{array}{l}87.35 \\
(12.04)^{\star *}\end{array}$ \\
$\begin{array}{l}\text { Higher } \\
\begin{array}{l}\text { education } \\
(n=438)\end{array}\end{array}$ & $\begin{array}{l}93.37 \\
(6.40)\end{array}$ & $\begin{array}{l}96.66 \\
(5.67)\end{array}$ & $92.23(7.61)$ & $\begin{array}{l}89.84 \\
(11.42)\end{array}$ & $\begin{array}{l}96.67 \\
(7.11)\end{array}$ & $\begin{array}{l}90.24 \\
(11.25)\end{array}$ \\
\hline
\end{tabular}

\section{Mothers} educational level

\begin{tabular}{|c|c|c|c|c|c|c|}
\hline $\begin{array}{l}\text { Basic } \\
\text { education } \\
(n=195)\end{array}$ & $\begin{array}{l}93.47 \\
(6.05)\end{array}$ & $\begin{array}{l}96.27 \\
(7.44)\end{array}$ & $92.56(7.08)$ & $\begin{array}{l}90.31 \\
(11.03)\end{array}$ & $\begin{array}{l}97.15 \\
(6.73)\end{array}$ & $\begin{array}{l}89.65 \\
(10.99)\end{array}$ \\
\hline $\begin{array}{l}\text { Higher } \\
\text { education } \\
(n=438)\end{array}$ & $\begin{array}{l}92.64 \\
(7.00)\end{array}$ & $\begin{array}{l}96.39 \\
(5.68)\end{array}$ & 91.33 (8.39) & $\begin{array}{l}88.77 \\
(12.50)\end{array}$ & $\begin{array}{l}96.19 \\
(8.01)\end{array}$ & $\begin{array}{l}89.22 \\
(11.81)\end{array}$ \\
\hline \multicolumn{7}{|l|}{$\begin{array}{l}\text { Working } \\
\text { parents }\end{array}$} \\
\hline $\begin{array}{l}\text { Both } \\
(n=285)\end{array}$ & $\begin{array}{l}93.27 \\
(6.63)\end{array}$ & $\begin{array}{l}96.36 \\
(5.34)\end{array}$ & 92.19 (8.03) & $\begin{array}{l}89.40 \\
(12.42)\end{array}$ & $\begin{array}{l}96.89 \\
(7.61)\end{array}$ & $\begin{array}{l}90.39 \\
(11.10)^{*}\end{array}$ \\
\hline $\begin{array}{l}\text { One or none } \\
(n=348)\end{array}$ & $\begin{array}{l}92.59 \\
(6.80)\end{array}$ & $\begin{array}{l}96.35 \\
(6.95)\end{array}$ & $91.32(8.00)$ & $\begin{array}{l}89.11 \\
(11.80)\end{array}$ & $\begin{array}{l}96.15 \\
(7.68)\end{array}$ & $\begin{array}{l}88.49 \\
(11.88)\end{array}$ \\
\hline
\end{tabular}


Insurance

\begin{tabular}{|c|c|c|c|c|c|c|}
\hline $\begin{array}{l}\text { Paid by } \\
\text { government } \\
\text { or have no } \\
\text { insurance } \\
(n=371)\end{array}$ & $\begin{array}{l}92.42 \\
(6.84)^{*}\end{array}$ & $\begin{array}{l}96.04 \\
(6.06)\end{array}$ & $91.16(8.07)^{\star}$ & $\begin{array}{l}88.91 \\
(11.98)\end{array}$ & $\begin{array}{l}96.15 \\
(7.95)\end{array}$ & $\begin{array}{l}88.37 \\
(11.37)^{*}\end{array}$ \\
\hline $\begin{array}{l}\text { Self- } \\
\text { funding } \\
(n=262)\end{array}$ & $\begin{array}{l}93.57 \\
(6.52)\end{array}$ & $\begin{array}{l}96.80 \\
(6.54)\end{array}$ & 92.49 (7.90) & $\begin{array}{l}89.71 \\
(12.21)\end{array}$ & $\begin{array}{l}96.97 \\
(7.18)\end{array}$ & $\begin{array}{l}90.69 \\
(11.22)\end{array}$ \\
\hline
\end{tabular}

${ }^{*} p<0.05 * * p<0.01$

Analysis using Independent -sample T-test; SD, standard deviation.

Table 5

Multivariate analysis of HRQOL Total score: self-report and proxy report

\begin{tabular}{|c|c|c|c|c|}
\hline \multirow[t]{2}{*}{ Variable } & \multirow{2}{*}{\multicolumn{2}{|c|}{$\begin{array}{l}\text { Self-report (total score) } \\
\mathrm{N}=510\end{array}$}} & \multicolumn{2}{|c|}{$\begin{array}{l}\text { Proxy report (total } \\
\text { score) }\end{array}$} \\
\hline & & & \multicolumn{2}{|l|}{$\mathrm{N}=612$} \\
\hline$n=612$ & Coefficient & $\mathrm{Cl} 95 \%$ & Coefficient & $\mathrm{Cl} 95 \%$ \\
\hline Age (2 to 12 years old= Ref) & & & $2.55^{\star \star}$ & $\begin{array}{l}1.49 \text { to } \\
3.61\end{array}$ \\
\hline Number of children (2= Ref) & $-1.78^{*}$ & $\begin{array}{l}-3.28 \text { to } \\
-0.17\end{array}$ & & \\
\hline $\begin{array}{l}\text { History of illness in the past } 1 \text { month } \\
\text { (healthy= Ref) }\end{array}$ & $-2.98 * \star$ & $\begin{array}{l}-4.52 \text { to } \\
-1.45\end{array}$ & $-3.00 * *$ & $\begin{array}{l}-4.02 \text { to } \\
-1.98\end{array}$ \\
\hline Birth weight (>2.500 gram= Ref) & & & $-2.46^{\star}$ & $\begin{array}{l}-4.54 \text { to } \\
-0.37\end{array}$ \\
\hline Mode of delivery (vaginal delivery= Ref) & & & $-1.45^{\star}$ & $\begin{array}{l}-2.80 \text { to } \\
-0.09\end{array}$ \\
\hline Living area (urban=ref) & $2.91 *$ & $\begin{array}{l}0.69 \text { to } \\
5.10\end{array}$ & & \\
\hline Fathers' educational level (higher level= Ref) & $-1.73^{\star}$ & $\begin{array}{l}-3.38 \text { to } \\
-0.08\end{array}$ & $-1.66^{\star}$ & $\begin{array}{l}-2.75 \text { to } \\
-0.56\end{array}$ \\
\hline Insurance (self-funding= Ref) & & & $-1.20^{\star}$ & $\begin{array}{l}-2.22 \text { to } \\
-0.19\end{array}$ \\
\hline & adjusted $R^{2}$ & 060 & adjusted $R^{2}$ & 128 \\
\hline
\end{tabular}

* $p<0.05 ; * \star p<0.01$

$\mathrm{Cl}$, confidence interval 